\title{
Study on Multiple Subjects' Role Orientation in Property Management
}

\author{
Yan Ding \\ School of Health and Pension Industry, Sichuan University of Arts and Science, Dazhou, China \\ Email: dingyan19849290@163.com
}

How to cite this paper: Ding, Y. (2019) Study on Multiple Subjects' Role Orientation in Property Management. Open Access Library Journal, 6: e5524.

https://doi.org/10.4236/oalib.1105524

Received: June 6, 2019

Accepted: June 21, 2019

Published: June 24, 2019

Copyright $\odot 2019$ by author(s) and Open Access Library Inc.

This work is licensed under the Creative

Commons Attribution International

License (CC BY 4.0).

http://creativecommons.org/licenses/by/4.0/

\section{(c) (i) Open Access}

\begin{abstract}
Property management is an important part of social management, which is directly related with national welfare and the people's livelihood. However, since there are multiple subjects participating in property management, the conflicts of multiple parties' interests lead to role misplacement of these subjects, which severely affects the development of the whole property management industry. Based on the situation of the subjects' role misplacement in property management in our country, the thesis proposes correct role orientation for multiple subjects and aims to provide certain theoretical reference for the healthy development of property management industry.
\end{abstract}

\section{Subject Areas}

General Management

\section{Keywords}

Property Management, Multiple Subjects, Role Orientation

\section{Introduction}

Property management is a highly systematic and comprehensive industry, in which many organizations and units are involved both directly and indirectly. Herein the subjects of property management refer to the enterprises or units directly participating in property management activities, which mainly include the government's competent administrative departments, assembly of owners and owner committee, and property service enterprises. Other organizations or enterprises indirectly participating in property activities are herein referred to as property management associated units, which include construction units, municipal administration, environmental sanitation, public security, industry and commerce, tax, price and other competent administrative departments, and 
public service departments such as water, power, gas and heating supply.

\section{Subjects' Role Misplacement and Incomplete Role in Property Management}

1) Incomplete role of the government's competent administrative departments

Property management is a part of urban management, and is also an important foundation for constructing harmonious society. Therefore, with regard to urban management and constructing harmonious society, the government shall provide correct guidance and effective supervision for property management, and promote the harmonious development of owners, property service enterprises and the government itself. However, the government does not play its role well as an administrator in property management practices, which is illustrated as follows:

a) Imperfect property management laws and regulations and poor practical operability

The most important tool for the government's competent administrative departments to administrate the property management market is to formulate complete and practical laws and regulations. At present, property management laws and regulations in our country are still imperfect, and there are many difficulties when dealing with problems in practice. For example, the existing laws do not provide clear answers for problems such as the legal status of owner committee, problems left over by the developer, the use of special maintenance fund, and difficulties of collecting property management fees. The imperfect legal system has become one of the important factors that hinder the development of property management.

b) Inadequate supervision from the government's competent administrative departments

Regulation on Realty Management stipulates that the government's competent administrative departments are responsible for the supervision of developers, property service enterprises, owner committee, etc. However, the competent administrative departments do not fully exercise its supervisory role in property management practices, which is mainly due to the following 3 reasons: i) The government departments consider property management disputes as trifles which are unnecessary to deal with [1]. ii) Property management starts late and is immature, as a result, when dealing with property management related issues, the government departments are obviously inexperienced, for example, many places do not have a special department to deal with property management problems , and when problems arise, they do not know which department to hand them over to. iii) Some public servants have related interests with property service enterprises and realty developers, therefore the relevant departments are biased when dealing with property disputes and exercising supervisory roles [2].

2) Role misplacement of property service enterprise 
a) Property service enterprises position themselves as "administrator" instead of service provider

Property service enterprises conduct property management activities, and most of them would position themselves as property administrator. In dealing with routine property management affairs, they tend to emphasize their own administration authority. They order the owners about, are seldom service-oriented, neglect the owners' reasonable demands, and do not earnestly fulfill the service terms stated in the property management contract, moreover, they even conduct activities that do harm to or encroach on the owners' interests. For example they block owners who did not take access card from entering the housing estate; they rent parking spaces (which should have been the owners' common property) to users outside the housing estate, and keep the income for their own.

b) Property service enterprises overvalue profitability and ignore services

It is understandable that as profit-making organizations, property service enterprises seek profits. However, in reality, property service enterprises make profits from complicated resources. Theoretically, most of their profits shall directly come from the property management fees paid by the owners, but in property management practices, the main profits come from operation income of public sites, public facilities and equipment, and public venues. These profits should have been the public income of all the owners, but now they are put into the property service enterprise's wallet, which severely infringes the owners' interests. Not only that, some property companies are also self-supporting many charging items, such as elevator usage fees, water and electricity reserve funds, etc. It makes it difficult for the owners to distinguish the true from the false. Due to the property companies' emphasis on their own economic interests, unauthorized reduction of service level, reduction of service items, reduction of service standards, and even illegal occupation of residential green space, arbitrary charges and other reasons, the property management industry disputes continue.

3) Role misplacement and incomplete role of owners and their organizations

a) "Hitchhiking" leads to the owners' weak subject consciousness and low involvement

Since property service has the attribute of public goods, many "hitchhiking" behaviors appear in property management. The Property Law and Regulation on Realty Management expressly stipulate that in each housing estate, owner committee is established according to law to protect the owners' interests. Generally speaking, the owners do not naturally have strong desire to establish an owner committee until they meet various problems in their daily life, cannot get the problems solved and need to protect their own rights [3]. For example, if the owners seldom meet problems, few of them are willing to take some time off and participate in property management of the housing estate. Basically, owner committee members can only hold meetings in their leisure time and passively perform their supervisory duties on property management activities, which defi- 
nitely will lead to incomplete subject status of owner committee, and the rights and functions granted by laws to owner committee will not be effectively implemented.

b) The owners wrongly position owner committee as the executor of their will

As a defender of the owners' interests, in the game with property service enterprises and the developers, owner committee represents all owners and try its best to prevent the owners' interests from being infringed. When conflicts arise between some owners and the property service enterprise, such owners may consider that owner committee only serves the owners, and shall support the owners regardless of right or wrong. Once their personal interests are not protected, such owners tend to blame owner committee's work unscrupulously. They will consider that the committee takes no action, and they may even doubt that the committee members have certain association with the property service company. As a result, it often drains the committee members of their enthusiasm. The owners have wrong cognition of owner committee, lack trust on the committee members, and seldom have desire to participate, which make owner committee cannot play its due role and exist in name only.

\section{Proper Positioning of Subjects in Property Management}

Due to the quasi public attribute of property service, property management also belongs to public management, and some problems that exist in property management can be explained by public governance theories. Public governance theories emphasize that the subject of social governance is not necessarily the government, and it shall not completely rely on the coercive power from the government. Such theories advocate that multiple subjects in the society shall fully play their roles and jointly participate in the administration of social public affairs. Accordingly, in property management, the government, the property service enterprises and the owners shall cooperate and coordinate with each other, clearly define their different roles and jointly exercise their due functions in property management resource allocation (Table 1).

Table 1. Influencing factors on the proper positioning of subjects in property management.

\begin{tabular}{|c|c|c|}
\hline Subjects & Purpose of participation & Influencing factors \\
\hline $\begin{array}{l}\text { The government's } \\
\text { competent } \\
\text { administrative } \\
\text { departments }\end{array}$ & $\begin{array}{l}\text { Strengthen supervision and service functions in } \\
\text { accordance with property management market } \\
\text { rules to make sure that the property management } \\
\text { industry develop healthily and smoothly }\end{array}$ & $\begin{array}{l}\text { Duties and responsibilities } \\
\text { are unclearly defined, } \\
\text { different departments } \\
\text { prevaricate and shift the } \\
\text { responsibilities onto others }\end{array}$ \\
\hline $\begin{array}{l}\text { Property service } \\
\text { enterprises }\end{array}$ & $\begin{array}{l}\text { Implement property management activities and } \\
\text { make profits in accordance with the contract }\end{array}$ & $\begin{array}{l}\text { Lower service quality to } \\
\text { reduce costs }\end{array}$ \\
\hline $\begin{array}{l}\text { Owners and their } \\
\text { organizations }\end{array}$ & $\begin{array}{l}\text { Represent all owners to manage property public } \\
\text { affairs and defend the owners' legal interests }\end{array}$ & $\begin{array}{l}\text { Poor participation from the } \\
\text { owners, and owner } \\
\text { committee members are } \\
\text { not professional }\end{array}$ \\
\hline
\end{tabular}


1) The government's competent administrative departments: the leader for the positive development of property management market

According to the government intervention theory of Joseph Eugene Stiglitz, the purpose of major functions of government administration is to create environment, wipe out obstacles, allocate resources, eliminate conflicts and to remedy the defects of market effect. During a more-than-three-decades development of property management market, the government plays multiple roles, such as market rule maker, referee during market operation process, market dispute mediator, market activity supervisor, etc. However, since multiple roles intertwine with each other, the corresponding duties and responsibilities of competent administrative departments are unclearly defined, and the administrative departments have wrong role orientation. It seems that they need to take charge of everything, and on the contrary, it seems that they are not responsible for many things, which can be dealt with by property service companies or owner committee at their own discretion. During property management, the government shall know what can be done and what cannot be done, play the leader's role to promote the positive development of property management market, exercise its due functions, neither "overstep" its role nor be "absent" from its due role. The leader's role of the government is mainly reflected in the following aspects:

a) Based on the development status of property management industry in different places at different periods, the government formulates property management related laws and regulations, and actively promotes legislative process to ensure that the laws and regulations are actually implemented. It shall actively establish healthy and positive environment for the development of property management industry.

b) The government coordinates the relations of participants in property management activities. Property management activities are socialized, in which many enterprises and departments are involved, such as government agencies (police, fire departments, environmental protection department, etc.), public affairs departments (water, power, gas, heating supply, etc.), and private enterprises (construction units, architectural decoration enterprises, property service enterprises, etc.). As a market subject that has special administrative power, the government can utilize its special identity to organize and sort out the relations of property management related parties, eliminate conflicts and serves as a bridge to promote cooperation of relevant parties.

c) The government supervises the behaviors of other subjects participating in property management activities. For example, it audits and assesses the qualification of property management enterprises, and provides guidance and supervision on the work of owner committee of the corresponding housing estate. With regard to some noncompliant behaviors in property management market, the government can exercise its power to intervene the market through relevant administrative agencies and administrative regulations to bring order to the mar- 
ket, enhance economic efficiency and stabilize social order.

With the acceleration of property management market progress, the property management market will be more and more mature, the government's administrative status in property management activities will be gradually weakened, and its leader's role for promoting the positive development of property management market will be further highlighted.

2) Property service enterprises: service provider with certain management functions

Not only does property service enterprise conduct wrong positioning on themselves as to their role in property management activities, the whole society, including government departments, also has unclear understanding on these enterprises' role. Although competent government department has changed "property management enterprises" in Regulations on Realty Management to "property service enterprises", the simple behavior of name changing did not fundamentally change the operation principles of property management enterprises. Nor does it fundamentally solve property disputes.

Robert C. Kyle, the founder of International Property Education Company, asserts that as professional property managers, property service enterprises provide professional services to the owners so that the property preserves its value and appreciates. The essence of property management fundamentally lies in professional services. However, in order to provide such professional services, it is necessary to exercise certain administrative functions, which is mainly because:

a) The government grants property service enterprises certain "administrative" functions.

At present, property management related laws and regulations in our country are still imperfect, and competent government departments are occupied and cannot spare time to deal with some illegal phenomena in property management activities. For example, behaviors such as illegal building by owners, unauthorized appropriation of public green space and noncompliant architectural decoration can only be "administrated" through the "assistance" of property service companies.

b) Owners have inadequate self-management ability

The property belongs to its owner, which fundamentally indicates that the property shall be managed at his/her own discretion. At present, however, most owners do not have professional management skills, nor do they have sufficient time, which makes it difficult for owners to conduct self management of their property. Therefore, a part of the "administrative" functions can only be exercised by the property service companies. In order to protect the interests of most owners, sometimes property service companies need to utilize the "administrative" functions to regulate the noncompliant behaviors of few owners.

Above all, in order to provide satisfactory services, the property service enterprises need to have certain administrative functions. But it shall be noted that 
the "administration" and "service" during the working process of property service enterprises are not on the same level. The administrative work of property service enterprises can only be conducted on the basis and under the guidance of service.

3) Owners and their organizations: leader of autonomous management within their housing estate

Owners and their organizations are the major participants of property management activities, to whom property service enterprises provide services. According to Regulations on Realty Management, individual owners do not have the subject qualification of dealing with important issues of property management, and the protection of their interests can only be implemented and expressed through assembly of owners and owner committee. As a result, the owners consider that owner committee always protects and enhances the interests and welfare of all owners. As a spontaneously formed organization, owner committee is a major leader within its housing estate, which is indicated as follows:

a) When the owner's interests are infringed, owner committee is the "spokesman" of the owners to protect their rights.

In property management activities, the owners and property service enterprises have both mutual benefits and conflicts and contradictions. On one hand, the owners hire property service companies to manage the public area and preserve public order of the housing estate so that they can jointly create a beautiful and harmonious property environment. On the other hand, the owners hope to pay less property fees for high quality property service, while property service companies hope to input less services or costs to obtain the highest earnings, which are contradictory. Therefore, in practice, the owners' interests are often infringed by property service companies, for example, property service companies may utilize public area to make earnings, or it may wantonly charge fees under assorted names. At such moments, owner committee shall stand out as a rights-defending person in the perspective of the owners and contend with property service enterprises to strive for maximum benefits for all owners.

b) Owner committee is a facilitator for the effective implementation of property services within the housing estate area.

One of the important functions granted by laws to owner committee is to conduct supervision on property services. For example, owner committee has the right to supervise and audit the income and expenditure account of the property service company, the earning status of public places of the housing estate, and the custody and utilization of special maintenance funds. But this does not mean that owner committee and the property service company is born to be "sworn enemies". The property service company and owner committee are both indispensable for improving the owners' living quality and for the value preservation and appreciation of their property. The property service enterprise provides professional services, while owner committee shall provide sufficient assis- 
tance. For example, owner committee can provide assistance to enhance the contribution rate of property fees, provide guidance and promote correct property consumption concepts, jointly hold activities to improve the relationship between each other, mediate conflicts between owners and the property service company, and provide assistance to the property service enterprise for work replacement and handover, etc.

As the leader of autonomous administration within the housing estate, owner committee shall not only protect the interests of all owners, it shall also guide the owners to cooperate with the property service enterprise so that better services can be provided and joint efforts can be paid to establish favorable environment of the housing estate.

\section{Conclusion}

Frequent property management disputes in property management practices have a great matter with the unclearly defined roles, duties and responsibilities of the subjects of property management activities. However, in clearly defining the relations between various subjects, the ideal perception that role orientation can eliminate all disputes and conflicts in property management shall be avoided, which is unrealistic both from theory and practice. Rational role orientation can be utilized to just reduce the conflicts in property management activities, and make the conflicts not so prominent and acute. Multiple parties shall jointly facilitate the co-governance to realize the cooperative target of "benefit sharing and win-win cooperation" among the government, the property service enterprises and the owners, and jointly pay efforts to establish harmonious housing estate and harmonious society.

\section{Fund Project}

Theoretical and practical study on how Dazhou can realize sharing-mode development. It is a phased research outcome of a 2019 scientific research project of Dazhou Social and Scientific Association. The project herein is supported by innovation team of Sichuan University of Arts and Science that conducts researches on development of community services (No. SASU 2014112-10).

\section{Conflicts of Interest}

The author declares no conflicts of interest regarding the publication of this paper.

\section{References}

[1] Peng, X.F. (2018) Study on Housing Estate Property Management Paths Based on Multiple Interests Coordination Theory. Modern Marketing.

[2] Ma, L.L. (2004) Study on Property Management Subjects and Their Functions. East China Normal University, Wuhan.

[3] Chen, P. (2013) Study on Owner Committee from the Tripartite Perspective of Country, Market and Society. Journal of Public Management, No. 3, 57. 